\title{
[2]
}

\section{What We Know about the Development of Social Policy}

\author{
COMPARATIVE AND HISTORICAL \\ RESEARCH IN COMPARATIVE \\ AND HISTORICAL PERSPECTIVE
}

\author{
Edwin Amenta
}

In 1975, two important quantitative comparative analyses of social policy were published. Harold Wilensky's The Welfare State and Equality addressed the differences in social spending efforts among sixty-odd countries in the 1960 s and found that the level of economic development and the age of populations accounted for most of the variance in efforts. This study was the best and latest in a series of cross-sectional analyses of countries and American states that suggested that economic and social modernization processes determined social policy (review in Skocpol and Amenta 1986). The second study, David Collier and Richard Messick's "Prerequisites versus Diffusion: Testing Alternative Explanations of Social Security Adoption," examined a similar group of countries, but with a wider time horizon, and addressed the adoption of social insurance policies. Their findings cast serious doubt on the modernization hypothesis, as well as on the strategy of generalizing from studies of many countries on social spending at a single point in time. Just a year earlier, Hugh Heclo had published Modern Social. Politics and Britain and Sweden, one of the first studies to take a comparative and historical approach to the development of social policy.

Previous versions of this essay were presented at the Conferences on Comparative Historical Analysis, Brown University, April 2000, and at Harvard University, November 2000, and the annual meeting of the American Political Science Association, 2001, San Francisco. My thanks to Ellen Benoit, Chris Bonastia, David Collier, Marshall Ganz, Jack Goldstone, Jeff Goodwin, Roger Gould, Peter Hall, Ira Katznelson, Bonnie Meguid, Gerardo Munck, Paul Pierson, Theda Skocpol, Kathy Thelen, Dietrich Rueschemeyer, and James Mahoney for helpful comments on previous versions of this essay. This work was supported in part by National Science Foundation Grant SBR-9709618. 
In the generation since then, we have learned a great deal about social policy - largely through comparative and historical work of the small- $N$ variety. On the empirical side, we have learned when various countries adopted social programs, when these programs were expanded or contracted, the forms that social policy has taken, when countries completed their systems of social policy, differences in social spending among countries at different points in time, and which countries have seen significant retrenchment in social policy of what sort. More important, comparative and historical work in this area has built our theoretical knowledge. It has been the source of or contributed to the three main theories of social policy and the welfare state, two of which came in reaction to quantitative research on the modernization thesis. At the same time, the history of social policy in comparative perspective has served as an empirical proving ground for hypotheses based on these theories. In turn, the comparative and historical research has led to the revision of theoretical arguments and has helped scholars to place scope conditions on theoretical generalizations, another way that scholarship can progress. Comparative and historical scholars have developed new methodological approaches, in particular by synthesizing comparative and historical and quantitative techniques in individual projects. Perhaps most important of all, comparative and historical research on social policy has jump-started various lines of research by asking some large questions and identifying empirical puzzles to solve and by deepening the concept of social policy. In transforming our understanding of social policy, these projects have aided theoretical refinement and advanced the research agenda in this area.

Why has there been such great progress? Partly it was because of broad conceptual agreement on what was important to study. In conducting their research, scholars tended to see social policy as lines of state action to reduce income insecurity and to provide minimum standards of income and services and thus to reduce inequalities. State programs that worked in these ways were called "social programs" or sometimes, more hopefully, "welfare state programs," with the whole of these programs known as "social policy." This understanding has anchored empirical analyses. It also mattered that scholars disagreed on the theoretical arguments best suited to explain

1 States were typically understood as dominant organizations exerting political authority and control over defined territories and their inhabitants. States that devoted most of their fiscal and bureaucratic efforts in these directions were and are considered to be "welfare states." Comparative and historical research centered on explaining differences in the adoption, the form, the extension, and sometimes the retrenchment of major social programs. 


\section{Development of Social Policy}

social policy while reaching broad agreement on the set of theoretical arguments deemed worth developing and appraising. Scholars focused on a few socioeconomic, political, or institutional arguments, which were often couched as parts of larger theories of the state or of politics. There were also informational preconditions - the ready availability of extensive historical records and comparative data. Finally, scholars as individuals and as a group had an open-minded outlook on methodology and theory. In this area, comparative and historical research engaged in an unusual and fruitful dialogue with quantitative cross-national work. The direction of the progress is due mainly to the relative strengths and weaknesses of comparative and historical approaches, which are well suited for identifying and addressing big questions, employing comparisons to rule out certain answers, appraising the mechanisms of theoretical arguments by tracing over time the processes of policy adoption and development, and developing new theoretical arguments, if weaker in providing strong tests of general hypotheses.

In what follows, I discuss some of the important things we know by way of comparative and historical analyses of social policy and the cumulation of knowledge in this area, including empirical, theoretical, and methodological growth. I also address why we know as much as we know and why the knowledge was able to build. I do this through a sort of comparative and historical approach, comparing over time the comparative and historical analysis of social policy with comparative and historical work in related areas. Mainly this is a theory-building project in the sociology of knowledge. I finish by addressing some new and promising lines of comparative and historical research on social policy and the challenges they face.

\section{Comparative and Historical Causal Research and Its Progress}

To ascertain the impact of comparative and historical causal research on the determinants of social policy, one needs to identify it. I see it not as a theory or a specific method or technique, but as an approach that has been undertaken by scholars with varied academic, theoretical, and methodological affiliations and preferences. By "comparative," I mean studies that address the experiences of two or more country cases (Lijphart 1971), but also one-country studies that situate empirical questions in a comparative context or make significant macrolevel comparisons in causal argumentation. Comparative studies do not have to use Mill's methods (Lieberson 1992), have a holistic understanding of the cases (Ragin 1987), or employ systemlevel variables to explain differences in within-in system relationships 
Table 3.1. Causal Research According to Metbodological Approaches

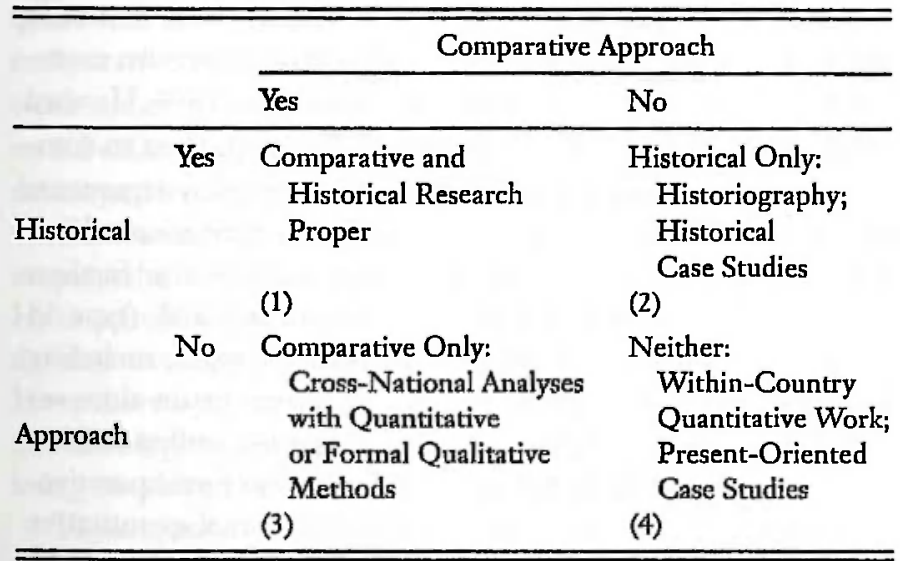

(Przeworski and Teune 1970). By "historical," I mean that the investigator situates the study within the relevant historical contexts, takes a sophisticated approach to historiography, thinks seriously about issues of process, timing, and historical trajectories, and gains a deep understanding of the cases. ${ }^{2}$ Historical work does not necessarily have to refer back more than fifty years, employ data not created by the researcher (Miriampolski and Hughes 1978), rely on secondary sources (Lustick 1996), take a narrative form, or make causal arguments based on sequences of events (Abbott 1992; Griffin 1992). Finally, to fit, studies have to take causality seriously in a double sense: to attempt to explain important historical differences or trajectories; and to appraise, modify, or produce something theoretically portable - a line of causal argumentation conceptualized so as to apply to other cases or time periods. ${ }^{3}$

Comparative and historical causal analyses in social policy appear in the box at the upper left of Table 3.1. This category, which I am calling "type 1, " includes major small- $N$ monographs such as Gaston Rimlinger's (1971) Welfare Policy and Industrialization in Europe, America, and Russia and Heclo's aforementioned Modern Social Politics in Britain and Sweden. Also included here, though, are quantitative and comparative and historical

This term was suggested to me by Peter Hall.

"Out of bounds would be what Skocpol and Somers (1980) refer to as "contrast of contexts" or what Charles Tilly (1984) refers to as "individualizing comparisons." 
Development of Social Policy

syntheses such as John Stephens's (1979) The Transition from Capitalism to Socialism and comparatively informed case studies such as Theda Skocpol's (1992) Protecting. Soldiers and Mothers (for some additional American examples, see also Katznelson and Pietrykowski 1991; Quadagno 1994; Howard 1997; Lieberman 1998). These studies situate U.S. developments in comparative perspective, employ comparative methods, and employ arguments that could be used outside the U.S. context. Studies without a causal impulse would fall outside Table 3.1, and the causal work that is furthest away from my concerns is situated at the lower right of the table (type 4). This category includes most within-country quantitative work, including testing general hypotheses on experiences of U.S. states or on time series of individual countries, as well as single-country case studies lacking a historical perspective. The most outstanding examples of comparativeonly work (at bottom left, type 3 ) are the many cross-national quantitative articles on social policy expenditures in the post-World War II period. ${ }^{4}$ The "historical only" type (2) includes historiography on social policy such as, to take famous American examples, Michael Katz's (1986) In the Shadow of the Poorbouse or James Patterson's (1986) America's Struggle Against Poverty.

To ascertain what we have learned from comparative and historical research in social policy means to ask, What would be lost if there had been no comparative and historical research in this area? And any answer to the question involves defining scholarly progress. To my way of thinking, an area has progressed if important questions have been identified and addressed and if informed, theoretically meaningful answers have been advanced by way of empirical demonstrations, with scholars using the results to formulate other questions, answering them in sophisticated ways that refine theory and lead to new questions, and so on. In the process, we appraise and develop new theoretical arguments, ascertain the conditions under which they apply or do not, refining theoretical argumentation along the way, and uncover new empirical facts and patterns as a result of new questions and theoretical development. This sort of advancement is not merely a matter of how much work exists on a subject or how frequently it is cited.

4 In this category I also place cross-national quantitative comparative analysis studies (Ragin 1994) and cross-national work relying mainly on Andrew Abbott's sequence analyses (Abbott and DeViney 1992) - as each methodological technique is based on algorithms that can be employed on preexisting or easily created data sets. These methods could, of course, be employed in work that is broadly comparative and historical (e.g., Wickham-Crowley 1992: conclusion). 
The issue may be easier to address by breaking it down into smaller questions: What have been the central gains in empirical knowledge from comparative and historical work on social policy? To what degree has this work added to our theoretical knowledge? Have causal hypotheses been tested extensively by this work in a way that refines them? Has theory been developed by this work, both in creating theory and in extending it? Have scholars deepened their concepts in terms of what is to be explained and employed these concepts to develop or delimit theoretical argumentation? Have scholars built on both the empirical and theoretical knowledge to develop new agendas of research that have promised or achieved progress? Have there been collateral benefits in other areas of scholarship, with new methodological advances made in the area and theoretical argumentation being employed to good effect in other areas?

These questions are not easy to answer either, but any attempt to do sn suggests that what we have learned from compararive and historical research in social policy is substantial and cumulative. Important gains have been made in empirical knowledge, much more so than one usually expects in comparative and historical work; the empirical knowledge has built on shared understandings about what is worth knowing and has filled gaps in what scholars want to know. There have been more significant theoretical gains. Comparative and historical research has made important contributions to the development of middle-range theory, devised from more overarching theoretical frameworks, to explain social policy. Theoretical gains have also come from appraising hypotheses on different sets of cases and time periods. Progress has been made especially in ruling out some aspects of broad generalizations and appraising the mechanisms of theoretical argumentation as they play out over time. Through hypothesisresting, theoretical arguments also have been modified - another important part of building knowledge. Some of the greatest means of advancement in this area, however, have come through the sorts of questions that have heen asked in comparative and historical research - questions that are not as easy to devise a suitable answer for in quantitative research - and the progressive development of the research agenda in this area. This develnpment has occurred through the process of asking research questions, advancing increasingly sophisticated and empirically supported answers to them, unearthing new anomalies in the process, leading to new questions, rentative answers, and so on. There have also been some important influcnces on other areas of study and on the development of methodological cechniques. Although these gains have come as a result of a process and 


\section{Development of Social Policy}

although individual projects have produced contributions across the board, let me begin with the empirical progress.

\section{Empirical Contributions of Comparative and Historical Research}

According to some standard views, comparative and historical research involves a division of labor in which historians work for social scientists: Historians write monographs centered on specific countries and issues surrounding the development of democracy, the progress of revolutions, and so on. Comparative historical social scientists reconceptualize the problem, ask the large comparative questions - why democracy or revolutions occur here and not there, and so on - scour historiography on several different countries and time periods regarding the surrounding issues, and then produce more comprehensive explanations that account for developments across these countries. In the process, they may dismiss the inessential and sometimes parochial arguments plausible to experts on one country alone. Such efforts, though, may be limited by the data or interpretations of the historiography on which they rely (Lustick 1996), even if scholars employ all extant historiography, as it might include conflicts in data or interpretations.

Social scientists working in the comparative and historical mode on social policy have often diverged from this model. Significantly, they often have gathered key information on which such higher-order analyses have been based and have been able to intervene in primary literature to make and defend their own interpretations. Social policy scholars did much of the initial digging that allowed the comparative questions to be framed and addressed. Also, where needed, comparative and historical scholars have supplemented historiography with their own archival work to fill in gaps in information or to adjudicate among historical interpretations, if needed. To understand how these processes worked and the knowledge gained by them, it is worthwhile to discuss what I call the "consensus on social policy" - the concepts social scientists employed and the typical ways that social policy was made operational in empirical study.

The consensus view was that modern social policy meant state efforts to reduce economic inequality by providing certain floors on income and services and preventing income losses due to certain risks. These perils include growing old and infirm; being injured at work; becoming ill, unhealthy, or disabled; becoming unemployed or underemployed; and being in a family where the principal wage earner or earners are incapacitated or 
Amenta

removed by these other risks or where there is no principal wage earner. The connection between inequality and insecurity of income was a close one, because a lack of programs to address risks to income was deemed to be a major cause of inequality and poverty. And, later, it was thought that the absence or destruction of programs to ensure security would increase inequality. Inequality or security typically was understood with reference to households. Research questions and projects were based on this common understanding of social policy. Into the 1990s, comparative and historical analyses of social policy typically focused on two things - the enactment of major social insurance programs and differences in the amount of social spending or "efforts" in social spending (see Skocpol and Amenta 1986; Amenta 1993). The focus of attention was modern social insurance and social assistance programs. The source of the consensus is not entirely clear, but the likeliest suspects are the U.S. Social Security Administration, which collected a great deal of information of use to both comparative historical and quantitative scholars (Rimlinger 1971; Wilensky 1975), and William Beveridge, whose impact went beyond designing what came to be known in Britain as the "welfare state."

This understanding of social policy had considerable appeal. It was easy to make the case that social policy mattered because it was at the center of the tremendous growth of states and changes in the character of many states in the twentieth century. It would be impossible to understand and explain the development of these states without understanding social policy, if only because of the sheer amount of money and bureaucratic effort expended on state old-age programs and health programs - especially in comparison with a century ago. Many states have been converted into welfare states - a pretty great transformation that is of interest to the thinking public as well as to scholars.

This conceptualization of social policy and the rationale for studying it helped to direct the research efforts of comparative and historical scholars. They relied on the research of historians, to be sure, but they also set out to ascertain through governmental records information regarding when social insurance programs were adopted in different countries and when they were expanded to include new segments of the citizenry. In short, they helped to set the parameters by which comparative and historical questions could be asked. The most outstanding examples of historical data collection serving conceptual understanding were the research projects of Peter Flora and associates, including The Development of Welfare States in Europe and America (1981) as well as Growth to Limits (1986) and the comparative 


\section{Development of Social Policy}

data collection of State, Economy, and Society in Western Europe, 1815-1975 (1983).

Individual comparative and historical researchers, however, also built our empirical knowledge by supplementing secondary sources and pursuing answers to questions by engaging in primary research. Although Theda Skocpol (1992), for instance, worked from many secondary sources in her study of American social policy through the 1920s, in calling attention to the role of Civil War veterans' benefits in providing substitutes for old-age and disability pensions, she also turned to primary documents, including numerous governmental records, to gain information unavailable in secondary sources, as this information was not collected according to conceptual agreements over the meaning of social policy. By using these primary sources and employing social science understandings of social policy, she was able to provide her own interpretation and analytical history of the development of U.S. social policy rather than relying on the interpretation of historians. Other scholars did the same, avoiding some of the problems of historical and comparative research - relying selectively on the interpretations or data in extant historiography (see the review in Amenta, Bonastia, and Caren 2001).

In their research, Peter Flora and Jens Alber (1981) also famously identified four periods in the development of social insurance programs in Europe and the United States: their adoption around the first decade of the twentieth century, their consolidation in the interwar years, their completion in the immediate postwar period, and their expansion in the decades after the war. It is probably agreed by now that the period comprising the last two decades of the century saw sustained bids to retrench social policy (Mishra 1990; Pierson 1994). This research facilitated the drawing of a group portrait of development of modern social policy over the last century or so for many countries, especially regarding when major programs were adopted. This periodization also proved useful in helping to set empirical research agendas, making it easier for scholars to devise new research questions and advance theory.

\section{Theoretical Advances}

Comparative and historical work in social policy has also made great theoretical contributions - probably more extensive than those in comparative and historical work in other subject areas. This is because comparative and historical scholarship in social policy has proposed and developed major 
Amenta

middle-range theoretical explanations of social policy, in one case by developing an entire perspective to explain anomalies. Theoretical advancement has also come in part through the testing and rejection of hypotheses and arguments based in modernization theory. The advances here have also included the refinement of theory through the testing of hypotheses by comparing social policy across country cases and tracing historical processes. Theory has also been refined by ascertaining the conditions under which certain causal factors have influences - a process that has gone hand in hand with the conceptual deepening of social policy. Because the work of comparative and historical scholars has often engaged the scholarship of quantitative comparative scholars, and because in some cases comparative historical and quantitative approaches were combined in single works, it is sometimes difficult to sort out the specific contributions of comparative and historical work. Yet it is not impossible to do so, and even by a conservative standard the comparative and historical contribution to theory building and refinement has been substantial.

Influential early work on social policy (e.g., Titmuss 1958; Peacock and Wiseman 1961; Marshall 1963) focused on post-World War II Britain's adoption of comprehensive public social provision and the term "welfare state." These studies, which fall outside my definition of comparative and historical because of their lack of comparative sensibility, argue from one case for the inevitably progressive influence on social provision of the expansion of citizen rights or the social solidarities forged in modern war.

It is perhaps not surprising that by the middle 1970 s, the arguments with the best comparative empirical support in explaining the development of social policy were not these British-centered ideas, but theoretical arguments based on modernization and industrialization processes. To simplify, the idea was that economic modernization would cause a series of events, including the aging of the population, the adoption of nuclear families, and increased economic surpluses that would lead to the rise and development of modern social policies everywhere and with it a change in the nature of the state. This line of argumentation mainly emerged in U.S.-centered und comparative quantitative work (see the review in Skocpol and Amenta 1986), though it was developed to some extent as well in comparative and hisrorical work (Rimlinger 1971). These arguments were also tested and finund wanting by quantitative researchers, who employed them to explain viriation across advanced capitalist democracies in the post-World War II pariod (see the review in Amenta 1993). But it was left to comparative and historical scholars to develop the historical implications of the arguments 


\section{Development of Social Policy}

(e.g., Flora and Alber 1981; Kuhnle 1981; Orloff and Skocpol 1984) in order to appraise them.

In the last two decades, two main theoretical arguments dominated thinking about comparative social policy, one of them mainly developed by way of comparative and historical work and the other almost entirely so. What might be called "political organizational" arguments hold basically that variation in the mobilization of political groups has determined the fate of social policy. Of these arguments, the best-supported explanation has been the social democratic or power resources thesis, based in Marxian theory. According to it, countries with large, centralized labor movements connected to social democratic political parties that govern political life are the likeliest candidates for extensive redistributive social spending. Although this argument has been stated in various ways, and although several scholars, some comparative and historical and some quantitative, approached similar ideas at around the same time (see the reviews in Shalev 1983; Esping-Andersen and van Kersbergen 1992), this argument received perhaps its most influential treatment in John D. Stephens's (1979) The Transition from Capitalism to Socialism - a work that employed both comparative and historical and quantitative approaches. The so-called Piven-Cloward hypothesis (1977), an alternative political argument about the impact of social movements on social policy, has been influential in U.S.-centered and quantitative studies and was developed through work at the borderline of comparative and historical scholarship (see the review in Skocpol and Amenta 1986).

The other main line of argumentation was institutional or state-centered, based on the ideas of Weber and Tocqueville (Skocpol 1985; Thelen and Steinmo 1992; Thelen 1999) and was developed almost entirely from comparative and historical work. The earliest and most extensive version of these arguments appeared in Heclo's (1974) Modern Social Politics and in Orloff and Skocpol's (1984) "Why Not Equal Protection?" and was extended in Skocpol's (1992) Protecting Soldiers and Mothers. Alternative political institutional arguments have been offered, notably in Ellen Immergut's (1992) Health Politics and Sven Steinmo's (1993) Taxation and Democracy. To simplify again, these scholars suggest that the adoption and development of social spending policies are encouraged by centralized political institutions and states with greater bureaucratic and financial capacities and are frustrated by fragmented political institutions and incapable states. The argument also specifies the conditions under which state domestic bureaucrats will have influence over policy making and in which directions. These state- or 
Amenta

polity-related arguments have been supplemented by other political institutional arguments about the influence of different forms of political party systems on social policy (Amenta 1998; see the review in Amenta et al. 2001). For the most part, this line of argumentation is structural and systemic and helps to explain long-run differences in policy formation and processes across countries.

The development of middle-range theoretical argumentation has gone beyond the creation of theoretical perspectives to the refinement of theoretical argumentation through comparative and historical empirical appraisals and the deepening of the concept of social policy. The social democratic hypothesis was importantly amended and transformed over time by comparative and historical work. From a focus on left-wing or social democratic parties in power, scholars have considered the role of the unified right-wing parties (Castles 1985), farmer-labor political coalitions (Esping-Andersen 1990), expert-labor alliances (Orloff 1993a), and Christian Democratic rule (van Kersbergen 1995). Similarly, the role of business organizations in influencing social policy has been treated in a more sophisticated manner (e.g., Swenson 1996; n.d.), seeking to sort out the conditions under which capitalists oppose or support some versions of social policy. Comparative and historical work has suggested that the role of capitalist support or secondary preferences for policy alternatives may be especially important in later phases of policy development, when policies have been in effect for a long time and have had the opportunity to restructure preferences (see the review in Pierson 2000a), as compared to the finding that capitalist organizations largely opposed social policy in its initial stages (Orloff and Parker 1990; Amenta 1998; Huber and Stephens 2001a). The left-party hypothesis has also been extended in work that addresses social policy in postcommunist Eastern Europe (Cook and Orenstein 1999; Rueschemeyer and Wolchik 1999).

Comparative and historical scholars have also gone on to build more theoretically synthetic or configurational arguments. Some of the more promising of these combine the structural strengths of institutional claims with those based on political identities and action (Skocpol 1992; Amenta 1998; Hicks 1999; Huber and Stephens 2001a; see the review in Amenta et al. 2001). These arguments rely on conjunctural or combinational causation (Ragin 1987; Katznelson 1997), in which different combinations of factors are hypothesized to bring about specific outcomes. Basically, political action is claimed to influence social policy development under some institutional conditions rather than others (Amenta 1998). Sometimes these 


\section{Development of Social Policy}

arguments have been appraised by way of formal qualitative comparative techniques (Hicks, Misra, and Ng 1995; Amenta and Poulsen 1996; Amenta and Halfmann 2000).

These theoretical refinements have come largely through the appraisal of hypotheses in comparative and historical work. In applying empirical tests, there was something like a division of labor between social scientists employing comparative and historical approaches and those employing quantitative cross-national analyses. Social scientists who did historical work often addressed the enactment and expansion of the "big five" social insurance programs - workers' compensation, old-age insurance, unemployment insurance, health insurance, and family allowances (Flora and Heidenheimer 1981) and their growth. There have been numerous case studies and close comparisons of the policy trajectories and fates of a few carefully chosen, economically developed nations (e.g., Rimlinger 1971; Heclo 1974; Stephens 1979; Flora and Heidenheimer 1981; Orloff and Skocpol 1984; Castles 1985; Esping-Andersen 1985, 1990; Baldwin 1990; Immergut 1992; Orloff 1993a; Steinmo 1993; Pierson 1994; Rueschemeyer and Skocpol 1996; Amenta 1998). In these latter studies, economic circumstances were held relatively constant. Divergences in the adoption of policy innovations and in the form of social spending systems have been explained by a range of factors, especially aspects of the state and political institutions such as the form and nature of bureaucracies and party systems.

Comparative and historical studies could do many things that quantitative studies could not in testing hypotheses. For one thing, they can examine the historical processes by which individual programs were adopted. Notably, the explicit or implicit mechanisms of these hypotheses could be given close scrutiny. To take one significant example in the social policy area, it was possible to ascertain whether social democratic parties were responsible for the adoption of initial social programs or whether these programs came in the wake of the campaigns of organized workers for them. The preponderance of this evidence was that social democratic parties did not hold power until after the period of initial adoption - that various sorts of liberal and centrist parties were the ones that enacted these programs (see the review in Amenta 1993). This has led some scholars to develop different arguments about the origins of social policy (Hicks 1999). To take another example, it was possible to ascertain whether the social problems associated with economic modernization brought generic social policy responses, as the modernization theory suggests. In the period between the world wars, however, what constituted a politically important threat to the incomes 
Amenta

of citizens varied, and countries took different approaches to protecting citizens from risks to income and employment and had not converged on specific policies to address these risks (Kuhnle 1981; Orloff and Skocpol 1984; Amenta 1998).

More generally, historical sequences could be examined to see whether developments were largely in line with theoretical claims (Rueschemeyer and Stephens 1997). This possibility was aided by the fact that the small- $N$ studies often were of the "most similar systems" type (Przeworski and Teune 1970), in which cases were similar on a number of theoretically relevant dimensions. A number of studies (beginning with Orloff and Skocpol 1984) were undertaken to understand why the United States did not move forward in developing specific social programs in crucial historical periods in comparison to countries with similar economic, political, legal, and cultural backgrounds, such as Canada and Britain. Case studies were now often done much differently than the pioneering studies by Titmuss and Marshall. The new studies were implicitly comparative in that policy developments in one country were analyzed with the backdrop of the experience of other countries informing them. That said, hypotheses have not been appraised mainly through a process in which scholars examine whether one or more cases seem to fit or contradict theoretical arguments, as in the literature on democratization and authoritarianism (see Mahoney, this volume), but have typically been appraised across different country cases in various studies that employ paired comparisons and argumentation based on methods like Mill's.

Although Mill's methods and similar ones have cast doubt on the most general claims of some arguments, the main advantage of this type of work has been in appraising hypotheses regarding the mechanisms of theories. It has also been possible through this work to see whether theoretical arguments are consistent with the origins of social policy - which has been difficult for quantitative work to address given the data difficulties. From here, scholars have been able to develop middle-range theory further. Ind so, comparative and historical work in social policy has exploited the advantages inherent in these sorts of analyses.

Comparative and historical research has some well-known disadvantages in appraising hypotheses, though. It is difficult to give arguments a rigorous test across complete populations of cases, for given the steep knowledge Ind informational requirements of comparative and historical work it is the iare comparative and historical study that can address the population of the dicoretically relevant cases (cf. Ertman 1997). There are often too many 


\section{Development of Social Policy}

hypotheses chasing too few observations, making it difficult to rule out some plausible alternative hypotheses. And case selection is almost never random, with the potential to lead to biases. As I will argue, however, comparative and historical research in this area has worked in a synchronic way with quantitative work to enhance the value of each means of appraising and developing theoretical argumentation.

\section{Conceptual Deepening, Big: Questions, and New Research Agendas}

Perhaps the greatest advantage of the small- $N$ studies and comparatively informed case studies was that they allowed scholars to ask the big questions about the development of social policy, setting off a process in which theories were developed or appraised or both, with theoretical refinements and conceptual deepening in studies leading to new questions to ask. It was possible for comparative and historical researchers to ask why some countries were leaders and laggards in social policy and why some countries had entirely different types of social policies from other countries - questions that were difficult for quantitative researchers to approach given the need for extensive comparable data across populations or large samples. Comparative and historical scholars were also free to rethink what social policy meant and to deepen the concept by exploring its boundaries, dividing it into processes, or lumping social policy development into larger types. In working from but questioning the consensus on the conceptualization and operationalization of social policy and helping to deepening the concept, comparative and historical scholars have aided the progress of theory and research. In this process, comparative and historical scholars have devised new questions and have opened new research agendas, helping to develop and refine theoretical argumentation.

Comparative and historical researchers have asked the big questions about the development of social policy, and they have not been restricted to asking questions only for which there are sufficient data on a population of cases to answer the questions. These questions have included the following: Why did social policy take off when it did, and why did it become so prevalent? Why did some countries lead and why did some others fall behind in different phases of the development of social policy? Why did some states adopt distinctive forms of social policy? By situating the experiences of different countries against the group portraits, comparative and historical scholars brought to light historical anomalies and puzzles to solve. In addressing these questions, these scholars also addressed hypotheses based 
Amenta

-n larger theoretical arguments, as noted previously, and in their historical research also challenged the focus of social policy research.

()ne important way that scholars have developed this research agenda a) id advanced theory is through taking seriously the phases of development in encial policy and the possibility that different aspects of social policy had different determinants. From this point of view, because they differ as proces ses, the adoption of social policy may be determined by different causes tha $\mathrm{n}$ its expansion or its retrenchment. The breaking down of social policy into different processes not only added to our empirical knowledge, but also he'ned scholars to form plausible research questions. One could exanine why one country was a late or early adopter, consolidator, or completer of standard social policy. The comparative work of Orloff (1993a) and Oinff and Skocpol (1984) on the adoption of social policy comes to mind hire. Even case studies were informed by this sort of thinking, however. In par icular, much has been written about the lateness of the U.S. adoption of st indard social policy and the incompleteness of its policy framework. The studies implicitly looked to European welfare states to attempt to explnin what made U.S. policy developments so different - with "different" usu, lly understood as backward in some respect (Skocpol 1992; Weir 1992; Quadagno 1994).

This conceptualization reflects back on theory in another way. By breaking racial policy into different processes, it is expected that conditions and variat les will have a different impact across them. Partisanship may have its great ast effect in the phases of adoption and consolidation, policy feedback has effects in the phases of expansion and retrenchment, and more systemic influences of the state likely have mediating effects all the way through. For inst nce. it has been argued with regard to the social democratic model that 2 perind of social democratic rule after the establishment of social policy may have less impact than when states have become welfare states. A given term of social democratic rule in the 1990s will thus have a smaller effect that in the 1930 s or 1940 s, when social policies were being adopted or chang:d in form (see, e.g., Hicks 1999).

Tins case for theorizing different processes separately has been made most iamously for the retrenchment of social policy. Pierson (1994) has argied convincingly that the retrenchment of social policy constitutes a differe nt process than the adoption of social policy. The basic idea is that cuttin $\mathrm{g}$ back a social policy is a more difficult process than adopting one and depends crucially on processes set in motion by the nature of the policy in quecrion. The argument has been deemed appropriate to explain social 


\section{Development of Social Policy}

policy developments since the 1980s (see also Huber and Stephens 2001a; Swank 2001). By this time, most systems of social spending had been completed and expanded - had become "institutionalized" - and bids to cut them back were taken up in force by many political regimes. Although there were international pressures on all states in this period, it may be useful to consider retrenchment as a recurrent possibility throughout the history of social policy with different determinants when social policy has been established as compared to when it is at an early stage of institutionalization. However one approaches it, this conceptualization of policy suggests that theoretical arguments need to be developed to explain specific processes in social policy.

The conceptualization of different phases of social policy by comparative and historical researchers has had an important impact on social science theory. It has been argued that the initial configuration of social policy influences its future in an important way - that the structure of social policy has important impacts on the politics of social policy and thus on its future (Esping-Andersen 1990; Skocpol 1992; Pierson 1994). From this way of thinking, policies have feedback effects that influence later social politics. This goes back to the distinctions made by Theodore Lowi in the $1960 \mathrm{~s}$ concerning the politics surrounding distributive and redistributive policies. Programs for poor people make poor programs in that the coalitions that can form behind them are likely to be weak. These arguments were conceptualized in ways that make it possible to construct and appraise theoretically coherent path-dependent arguments (see Abbott 1992; Griffin 1992; Mahoney 2000; Pierson 2000b). Notably, this sort of claim has been made and addressed in work ranging from explaining the origins of socia] policy (Skocpol 1992) and economic policy (Weir 1992) to work explaining efforts to retrench it (Pierson 1994).

Comparative and historical scholars have been able as well to appraise theoretical arguments by addressing social programs other than the main social programs that are usually summarized in quantitative work. Comparative and historical scholars have noted other state programs that addressed economic inequality or insecurity, and these scholars in turn have examined other state policy responses to basic societal risks to employment. income, and economic security (Weir, Orloff, and Skocpol 1988). These scholars have also recognized that social relations in the modern capitalist and democratic world produce a number of perils to income beyond the standard ones for which states have developed responses. And so, they have explored causal arguments about the determinants of social policy on new empirical terrain. 
There has been no shortage of programs offered for analysis by comnarative and historical researchers. Among the possibilities were veterans' henefits (Skocpol 1992), education (Heidenheimer 1981; Katznelson and Weir 1985; de Swaan 1988), taxation policy (Steinmo 1993; Howard 1997), brousing policy (Pierson 1994; Castles 1998; Bonastia 2000), economic polcviHall 1986; Weir 1992), drug policies (Benoit 2000), and work programs (imenta 1998). In each instance, it was argued that the line of state action and important impacts on economic insecurity and inequality and that res earchers ignored these policies at their peril.

Indeed, in addressing programs outside the standard boundaries, scholars of wn argued that an entire country case or set of cases should be reinterpreted. One of the more famous is Skocpol's (1992) claim that Civil War vet:rans' benefits were more generous than European old-age and disability programs, though restricted to groups other than industrial workers. Chers (Steinmo 1993; Howard 1997; Myles and Pierson 1998) argued that tax crion expenditures need to be addressed in order to understand social policy. U.S. social policy may not be backward, given the great efforts in this area, but merely different in form. To take my favorite example, I (Amenta 1908) show through the conventional modes of measurement of spending effort that work policies during the New Deal made the United States one of the world's leaders in the late 1930s. Sometimes, however, U.S. policy was seen to be even more backward than was previously thought, as in the case of economic policy (Weir 1992). Reinterpretations were also suggested by ralvses of education as social policy (Heidenheimer 1981; Katznelson and Veir 1985) and explorations of home ownership as a possible functional subs stute for social insurance programs (Castles 1998; Conley 2000). These stulicu place social policy in a different light, in addition to showing the distin stiveness of individual cases, and have promoted the asking of new its'inns.

C.mparative and historical research has been important in the developm nt of two other conceptualizations of social policy: ideal types that characterize policies as whole. Building on previous models of social policy, E-ping-Andersen's (1990) "welfare state regimes" address social policy's influrnce on labor-market relations. According to this scheme, the "social demceratic" regime, often seen in Nordic countries, is best for workers; it is bas: $\mathrm{d}$ nn the principles of universalism and "decommodification"; workers are freed from inequality due to the need to take what labor markets offer. Typically seen in continental Europe, the second-best "conservative corportist" regime is also universal but does not smooth status distinctions 


\section{Development of Social Policy}

between groups and upholds the traditional family, with a male breadwinner bringing home a family wage. The "liberal" welfare regime, the most inferior, is designed to make labor markets run smoothly at the expense of people; public social policy has a small presence and a large means-tested component, and is augmented by private control over areas elsewhere handled by states (see also Castles and Mitchell 1993; Huber and Stephens 2001a). Although these concepts have been contested as guides to historical research, they have been used to good advantage in research on retrenchment over the last two decades, as different configurations of social policy have been shown to pose different possibilities for retrenchment (Pierson 2000c).

New conceptualizations of social policy have also been provided by feminist scholars (reviews in Orloff 1996; Haney 2000; Pierson 2000a), many of whom work in a comparative and historical mode (Skocpol 1992; Pedersen 1993; Sainsbury 1996; O'Connor, Orloff, and Shaver 1999). The main responses have been to modify Esping-Andersen's types or to replace them with gender-based policy regimes. Orloff (1993b), for instance, adopts Esping-Andersen's types, but transforms them by adding new dimensions, including access to paid labor and the ability to establish an autonomous household. Indeed, decommodification may not be helpful for many women, and access to paid work for women, "commodifying" them, often promotes their financial autonomy from men (O'Connor 1993; Orloff 1993b). Thus, policy supporting equal participation in the paid labor force, as through antidiscrimination and comparable worth programs, tends to free women from potentially onerous reliance on men as breadwinners. By contrast, Sainsbury (1996) replaces Esping-Andersen's types with two based on unequal gender relations - the breadwinner and individual models and employs a number of different dimensions to separate the types. All agree, though, that a focus on the relationship between policy and gender inequality raises difficult issues that differ from those concerning policy and economic inequality. State transfer programs that tend to alleviate economic inequality among households may have little influence on inequalities between sexes or may even reinforce them (see also Esping-Andersen 1999).

\section{Impact on Other Types of Research and Methodology}

Comparative and historical research has also had an impact on other types of causal research, including cross-national quantitative and historical work on social policy and work in other areas. Notably, comparative and historical 
work in social policy has helped to generate theoretical arguments to be tested on larger data sets, just as cross-national quantitative work has provided hypotheses for comparative and historical appraisal. The comparative and historical work has also had an impact on strictly historical work, as historians are using the results of this literature to conceptualize, frame, justify, and develop their own projects. Comparative and historical work has also brought methodological contributions.

Comparative quantitative studies typically addressed the amount of spending on social policy in relation to a country's income or national product - to show how much effort was being put into state initiatives against inequality or insecurity - using the country (or country-year) as the unit of analysis. To summarize ruthlessly, social scientists began with quantitative, cross-sectional studies of all the countries of the post-World War II world (e.g., Cutright 1965; Wilensky 1975) and typically found that socioeconomic "modernization," especially industrialization and the aging of the population, underlay social spending differences. U.S. states, with their large populations and extensive socioeconomic variation, were also used as quantitative laboratories to test these propositions and others with respect to policy innovation and spending (e.g., Dye 1966; Sharkansky and Hofferbert 1969). Soon, however, quantitative scholars began focusing on the postwar experiences of capitalist democracies, which provided theoretical rather than proper-name scope conditions for causal claims; scholars argued that wealthy capitalist democracies would have determinants of social policy that differed from those of other sorts of polities. The most widely supported argument was a version of the social democratic argument. These studies, especially those that pooled cross-sectional and time series data, provided a sufficient number of observations to test hypotheses against one another, and data from the 1960 s on were relatively complete in coverage (see the discussion in Amenta 1993).

Quantitative analyses of postwar capitalist democracies have done well to attempt to appraise some aspects of the institutional arguments often seen in the small- $N$ historical studies. An influential article by Huber, Ragin, and Stephens (1993) addresses the effects of political or constitutional structures that hinder slim electoral majorities from enacting policy and that abet obstructionism from small groups - taking an insight from institutional theory and attempting to merge it with argumentation concerning the impact of social democratic and Christian Democratic political parties. In my own quantitative collaborations on American policy (e.g., Amenta and Poulsen 1996; Cauthen and Amenta 1996; Amenta and Halfmann 2000), I address 


\section{Development of Social Policy}

hard-to-operationalize statist arguments as well as versions of political ones in examining outcomes deemed important from historical investigations.

This line of research, however, suffered from limitations even in settling the debates about the expansion of social policy in these types of polities. One limitation based on data deficits was that it was difficult to appraise some theories. Given their structural and sometimes more complicated nature, the statist and institutional theories were more difficult to assess than the political ones. Part of the problem is that the relevant data were not readily available, as no international organization was collecting them. Even among the political arguments, it was easier to appraise the ones based on the institutional politics of elections, cabinet formation, and labor movements rather than the information-poor activity of social movements. Even in studies that used the same indicators, researchers debated their meaning, as Hicks and Mishra (1993) and Huber et al. (1993) interpreted economic indicators differently from each other, as well as differently from modernization theorists. More important limitations rested on the type of research and the empirical setting to which it was confined. Very few of these countries developed new and large social spending programs since 1960. Thus this type of research has been unable to address critical phenomena such as the timing and content of innovations in public spending.

There were some important quantitative comparative studies of the early years of social programs (e.g., Collier and Messick 1975; Schneider 1982; Hage, Hanneman, and Gargon 1989) and quantitative work within countries (Wright 1974; Skocpol et al. 1993; Steinmetz 1993; Cauthen and Amenta 1996), but given the less than comprehensive nature of the case coverage and data coverage of hypotheses, work like this was far from definitive. As a result of comparative and historical work, however, quantitative studies have been executed with increasing and considerable historical sophistication. Close attention is paid to time periods. A particularly powerful example of this is Alexander Hicks's Social Democracy and Welfare Capitalism (1999), in which comparative quantitative analyses, as well as Boolean qualitative comparative analyses, are employed on different periods of welfare state development. Scholars have done much better in matching theoretical concepts to historically appropriate indicators, especially in what I call "synthetic modes of analysis."

Comparative and historical researchers have made important methodological contributions, notably including true syntheses of quantitative and comparative and historical analyses. By this, I mean something different from King, Keohane, and Verba's (1994) injunction to use different data sets 
in rest the same lines of argument (see also Ragin 1987, pp. 82-4). Studies have been able to address large questions about differences in timing or trajectories or outcomes in social policy by examining a few cases or one case in a comparative context. In these analyses, it is possible to develop and tentatively appraise relatively complex arguments, sometimes involving multiple and conjunctural causation (Ragin 1987), sometimes involving mechanisms of process. Standard quantitative techniques have difficulty in assessing these more complex arguments, much as standard comparajue and historical work can provide only rudimentary tests of hypotheses. All the same, some comparative and historical studies have gone on it appraise as far as possible these complex arguments on relevant crossnational data sets or data sets on subunits within a country. By juxtaposing tine results of the one to the other, one can then modify the arguments. in sncial science, most scholars are comfortable with one style of research, and so the willingness and ability of individual scholars in this literature to. combine methodological approaches, sometimes in a single work, is remarkable.

The pioneering synthetic work was John Stephens's (1979) The Transitim from Capitalism to Socialisn, in which comparative quantitative studies trere augmented with comparative and historical analyses of a few countries. Jo in Myles's (1984/1989) Old Age in the Welfare State also has something of this quality. Other examples come from scholars who employ different techniques on the same subject matter across different works (Pampel wd Williamson 1989; Skocpol 1992; Skocpol et al. 1993; Williamson and Pa mpel 1993). In Bold Relief (1998), for instance, I appraise a conjunctural institutional politics theory by way of a historical analysis of the United S.ares during the 1930s and 1940s and in comparison with Britain. I also examine historical trajectories in policy across four states and appraise the argument on state-level data sets, whose indicators of social policy are inforned by the historical work. In related projects I employ Boolean qualit rive comparative analyses, which can address the configurations in the in rirutional and political arguments (Amenta and Poulsen 1996; Amenta a'c! Halfinann 2000). Evelyne Huber and John Stephens return to the syn hetic mode of analysis in their Development and Crisis of the Welfare State (2001a), which addresses the rise of welfare states as well as efforts at rarenchment over the last decades. They join pooled time series and cro:s-sectional regression analyses with detailed case histories of different 1.pes of highly developed welfare states in examining the development of social policy over long periods. The latter are used in order to get around 


\section{Development of Social Policy}

the short-term biases in regression analyses and to closely examine critical periods of policy development.

The comparative and historical work on social policy inspired other work that employed other formal qualitative and medium- $N$ methodologies, like sequence analyses and Boolean qualitative comparative analysis (Abbott and DeViney 1992; Ragin 1994; Hicks et al. 1995). And although the use of methodological techniques like qualitative comparative analysis and sequence analyses does not in itself make for a comparative and historical study, scholars have been able to explore these analyses on social policy cases because of comparative and historical work. As I suggest later, this sort of work is possible because of a consensus on what is to be explained and the ease with which outcomes and arguments can be operationalized into categorical or sequence variables. And as I noted previously, in some instances these investigations have been influenced by comparative and historical work, even if these scholars were not working in a strictly synthetic way.

Comparative and historical analyses of social policy have also had an impact on standard historiography and one-country studies. To take U.S. examples again, historiography on social policy now frequently locates historical questions about the development of social policy by way of findings and conceptualizations from comparative and historical work. This change can be seen, for instance, by comparing Edward Berkowitz and Kim McQuaid's (1980) Creating the Welfare State with its second edition (1988) or with Berkowitz's (1991) America's Welfare State. Similarly, U.S.centered historical classics on social policy, such as Frances Fox Piven and Richard A. Cloward's (1971/1993) Regulating the Poor, have been revised by way of reflection on this literature. Recent historical studies of U.S. taxation (Brownlee 1997; Zelizer 1999), for instance, have been influenced by the comparative and historical literature on the welfare state. As a result of this cross-fertilization, it has become difficult to separate out the impact of comparative historical work on this new historiography, as it now often resembles comparative and historical work in its concern to place historical developments in a comparative context in order to explain them.

Since the 1970s we have learned much about social policy through comparative and historical work. In 1975, Harold Wilensky could examine a cross section of nations and argue that processes of industrialization drove social spending. Today no quantitative study would argue that an analysis of a snapshot of a large number of countries could appraise complex theoretical arguments. In the meantime, because of comparative and historical work, 
Ainenta

there have been many new empirical findings, new theoretical perspectives, empirical appraisals across different cases and time periods, the deepening of the concept of social policy through both aggregation and disaggregation, theoretical refinements due to empirical appraisals and conceptual deepening, and a research agenda that has moved from question to question. What accounts for this progress and greatly increased sophistication?

\section{Why Comparative and Historical Research in Social Policy Was So Productive}

To address this question, I place the comparative and historical research on social policy of the 1980s and early 1990s in comparative and historical perspective. That is, I juxtapose it with the research programs that went before and with some current lines of research, and I compare comparative and historical work on social policy with comparative and historical work in related areas. Another political sociology area that I work in - social movements - has received as much attention if not more but has not, I would submit, advanced as far in either comparative and historical or quantitative work I would also venture to say that the area of social policy has progressed further, and progressed further through comparative and historical work, than the other areas reviewed in this volume. My discussion is speculative, as Thave not reviewed in detail the other literatures, and is mainly an exercise in theory building, but for ease of presentation I will state the points as baldly as possible.

The literature on social policy has advanced as far as it has partly because there was relative agreement on what was to be explained, while there was disagreement over the possible explanations. Although the standard definition of social policy was more like an anchor than a fixed standpoint, this sort of consensus about what was to be explained turned everyone's dicention in a similar direction. At the same time, scholars tended to disagree about the potential explanations. This situation promotes the testing of aypotheses and the development of middle-range social science theory in the tirst instance because it gives researchers with attachments to different neoretical perspectives something with which to appraise their arguments. It also provides ways of sharpening arguments as scholars assess how far they go to explain something of agreed-upon importance and to think about why arguments are limited. Having scholars with allegiances to different ineuretical arguments ensures a lively debate over the degree and nature of the empirical support. Having an agreement on what is to be explained 


\section{Development of Social Policy}

Table 3.2. Research Programus According to Agreement and Disagreement on What Is to Be Explained and the Explanation

\begin{tabular}{|c|c|c|c|}
\hline & & \multicolumn{2}{|c|}{ Explanation } \\
\hline & & Disagreement & Agreement \\
\hline \multirow[t]{2}{*}{$\begin{array}{l}\text { To Be } \\
\text { Explained }\end{array}$} & Agreement & $\begin{array}{l}\text { Recurvent Appraisals of } \\
\text { Alternative Hypotbeses: } \\
\text { Social Policy }\end{array}$ & $\begin{array}{l}\text { Reiterated Hypothesis } \\
\text { Testing: }\end{array}$ \\
\hline & Disagreement & $\begin{array}{l}\text { Conceptual } \\
\quad \text { Proliferation: }\end{array}$ & $\begin{array}{l}\text { Appraisals of Same Hypotheses } \\
\text { on Nezv Outcomes: } \\
\text { Social Movement }\end{array}$ \\
\hline
\end{tabular}

also helps scholars to locate empirical anomalies and to seek explanations for them.

The different possibilities regarding agreement and disagreement on what is to be explained and potential explanations are outlined in 'Table 3.2. At the upper left of the table is the situation in which scholars of social policy and the welfare state found themselves during the 1980s and early 1990s. There was relatively high agreement on what was to be explained - the adoption and expansion of major social programs - but relative disagreement among theoretical perspectives. Socioeconomic modernization theories were appraised alongside various Marxian political theories and statecentered or institutional theories. This situation did not preclude others with wholly different perspectives from trying their hand as well. It helped, too, that most of the theoretical arguments made were of the middle-range sort. This situation results in what I am calling "recurrent appraisals of alternative hypotheses." Scholars would be able to find different research sites to appraise and develop arguments. This entertaining of more than one argument may have aided the process by which different scholars moved away from relatively one-sided theoretical arguments - such as strictly social democratic or statist arguments - to more hybrid ones (cf. Orloff and Skocpol 1984 and Skocpol 1992; cf. Stephens 1979 and Huber et al. 1993).

In the area of social movements, by contrast, there is relatively little agreement on what is to be explained, with more substantial agreement on the theoretical perspectives. "Social movement" has no one meaning that scholars rally around. It has been held to refer to everything from a desire in public opinion for change to the creation of specific organizations to redress inequalities among the relatively powerless to the noninstitutional political action engaged in by such groups. Perhaps for this reason, scholars have 
addressed a wide variety of social movement outcomes, including the timing of the emergence of social movements, resources gained by them, who participates, the numbers of participants, their techniques of protest, the potential results of movements, and so on (reviewed in McAdam, McCarthy, and Zald 1988). Even if one were to say that the emergence of movements is the most important question, because of disagreements in the definition of social movements this is difficult to assess. There is also more or less agreement on the theoretical program advanced by Doug McAdam, John D. McCarthy, and Mayer Zald (1996) that social movement phenomena can be understood and explained by processes of framing, mobilization structures, and political opportunities. Again, the match is not perfect, but in general the situation is one in which the same theoretical arguments are applied to different sets of outcomes to see whether there is an empirical 6it. Most of the work in this area is by way of case studies of individual movements or organizations, but there is some comparative and historical vurk. It is possible to create different sorts of balance sheets here, with the results for a set of hypotheses juxtaposed to different outcomes. Because $\because \rightarrow$ the various conceptual and data problems, however, such balance sheets wuuld be more difficult to construct.

A second reason for the progress in social policy was the nature of the cunsensus on what was to be explained. It was useful in ways that went bevind the advantages of agreement. Social policy was conceptualized in ways nai were easy to operationalize but far from simplistic. It could sometimes ie studied in an all-or-nothing way, as in the timing of adoption of programs, -hich is easier to pinpoint than the emergence of a social movement. But tiere were more variegated ways to bring it down to earth it as well. Scholars fruased on a specific set of state activities and programs, with some more impe rant than others given their likely impact on insecurity and inequality. It was deemed important to analyze some specific programs, and it was possib. to add up social policy in meaningful ways. The programs were relatively fe w. making it possible to develop research projects examining them all. But each of the programs had enough going for it so that one could write an entre historical monograph on a specific program - not to mention a quantita ive research paper. Having basic agreement on an operationalization of so ial policy also made it clear when and where one was disagreeing with itani $\mathrm{l}$ i was possible to learn from that as well. The concept was sometimes dis iggregated or aggregated in other useful ways, as when different procesics ot social policy or larger ideal types of social policy were examined. I believe that the advantages are more epistemological than ontological - that 


\section{Development of Social Policy}

is, due to the way that the phenomena have been understood than with the nature of the phenomena themselves (cf. Hall, this volume).

Third, a good deal of relevant information about social policy was available. It was not that reams of new data were being collected by researchers - almost all the data were historical in the sense of being gleaned from the data-generating projects of organizations, mainly states and intergovernmental organizations. Abundant relevant historical documents were available, as one would expect with the object of the analysis being state activity, and they probably were more informative than those used in the classic literature on state formation given the great increases in bureaucratization of states in the twentieth century. This wealth of information eased the writing of the high-quality historiography and other secondary sources on which comparative and historical work greatly relies. The ready availability of governmental records also opened the way for social scientists to do their own targeted archival work as needed, without extensive costs. And the data were useful for theoretical purposes as well, because the units of observation were not merely a convenience, an aggregation of activity and relationships within the borders of a given country, but lines of action taken by the state, indicating relationships between the state and citizens. The ability of governments to keep good records and quantitative data matters much, and that may be attested to by the relative lack of comprehensive comparative research on poorer countries (for exceptions, see Pampel and Williamson 1989; review in Skocpol and Amenta 1986).

There were special benefits as well to the variability in the availability in forms of data. Hard and systematic data suitable for quantitative studies existed only for the periods of expansion and retrenchment, while less complete information of this sort was available for the periods of adoption, consolidation, and completion. This led to a division of labor of sorts, as Table 3.3 suggests. Quantitative comparative researchers mainly analyzed data from the 1960 s and beyond, and comparative and historical researchers took charge of the first half of the century. The comparative and historical researchers tended to work where the historical perspective had the greatest room to maneuver, and they were more likely to leave more recent developments to those working with quantitative techniques. The relative deficiency of hard data in the earlier period probably prevented the quantitative researchers from preempting the possibilities of historical research. There was a great deal of interesting work as well, however, on the off-diagonal situations noted in Table 3.3, and these studies were often sites of innovation and spurs to analysis of the other variety. Mary Ruggie 
Table 3.3. Research in Social Policy According to Time Period and Metbodology

\begin{tabular}{|c|c|c|c|}
\hline & & \multicolumn{2}{|r|}{ Methodology } \\
\hline & & Comparative/Historical & Quantitative/Formal Qualitative \\
\hline $\begin{array}{l}\text { Time } \\
\text { Period }\end{array}$ & $\begin{array}{l}\text { Pre-Second } \\
\text { World War }\end{array}$ & $\begin{array}{l}\text { Historical Perspective } \\
\text { Expanded: } \\
\text { Most comparative and } \\
\text { historical research } \\
\\
\text { Historical Perspective } \\
\text { Diminisbed: } \\
\text { Ruggie 1984; Hall } \\
\text { 1986; Pierson 1994; } \\
\text { O'Connor et al. } 1999\end{array}$ & $\begin{array}{l}\text { Hard Data Scarce; } \\
\text { Collier and Messick 1975; } \\
\text { Schneider 1982; Abbott and } \\
\text { DeViney 1992; Hicks et al. 1995; } \\
\text { Cauthen and Amenta } 1996 \\
\text { Hard Data Abundant: } \\
\text { Most comparative quantitative work }\end{array}$ \\
\hline
\end{tabular}

1984), for instance, addressed the impact of social policy on gender relarions, and Paul Pierson (1994) opened a new line of thinking and research on retrenchment, providing hypotheses addressed later by quantitative reearchers. The quantitative article by Collier and Messick (1975) cast great doubt on the modernization thesis with respect to the adoption of social policy and spurred comparative and historical work on this question.

The fourth reason was the open-minded methodological outlook of many of the prominent researchers in the area. The social scientists studying social policy were well versed in debates over comparative and histurical methods, and few took a hard line in favor of one over another. Ithough scholars had preferences for one or another line of work, they ra rely denigrated the work of others. Few quantitative researchers derided the work of comparative and historical researchers as soft or lacking in rigor. Few comparative and historical researchers saw the work of the quantitative scholars as simplistic and lacking in depth and validity. The tone was set early on, with Gaston Rimlinger (1971) employing the gold standard of puantitative studies, the measure of social spending "effort," to situate his path-breaking comparative and historical investigations. The willingness and ability of researchers to work in different modes was key. John Stephens. Evelyne Huber, Theda Skocpol, and Gøsta Esping-Andersen were prominent among those scholars proficient in one type of methodology bur willing or driven sometimes to employ others. Attempting studies in different modes was not the typical response of most individual scholars in this area, but the research of the one set of scholars was required 


\section{Development of Social Policy}

Table 3.4. Comparative and Historical Research Programs According to Presence of Quantitative Work and Its Engagernent with Comparative and Historical Researcls

\begin{tabular}{|c|c|c|c|}
\hline & & \multicolumn{2}{|c|}{ Presence of Quantitative Work } \\
\hline & & Strong & Weak \\
\hline \multirow{2}{*}{$\begin{array}{l}\text { Engagement with } \\
\text { Comparative and } \\
\text { Historical Work }\end{array}$} & Strong & $\begin{array}{l}\text { Synergy: Social Policy and } \\
\text { Welfare State Literature }\end{array}$ & $\begin{array}{l}\text { Diminished Synergy: } \\
\text { Literature on Revolutions }\end{array}$ \\
\hline & Weak & Synergy Failure: NA & $\begin{array}{l}\text { Synergy Impossible: Social } \\
\text { Movement Literature }\end{array}$ \\
\hline
\end{tabular}

reading for the other. These scholars understood that different approaches had advantages and disadvantages, and instead of accenting the disadvantages in each, scholars exploited the advantages in each to allow greater progress than could be achieved by one or another approach.

Conceptual agreement on social policy, the ability to operationalize it in sophisticated ways, the availability of different types of data to do so, and the willingness of scholars to address both types of analysis - all of this generated a synergy between comparative and historical and comparative quantitative work. The favorable situation faced by those working in social policy is depicted in the upper left part of Table 3.4, which arrays the presence of quantitative work with its engagement with comparative and historical work. Here there was a strong presence of quantitative work and a strong engagement with comparative and historical research. The result is that the advantages of each type of research benefited the other in ways that led to greater achievements than would have been possible on their own.

Other areas of research do not have the same sort of connection between comparative and historical and quantitative work. In the category at the bottom right, where there is little quantitative comparative work and little connection between it and comparative and historical work, synergy of this sort is not possible. I place the recent academic literature on social movements here (see the reviews in McAdam et al. 1988; Guigni 1998). In this instance, the relative lack of quantitative comparative work is due in part to lack of agreement among researchers in this area about what is important to explain. Also, there are no extensive data, perhaps because of the relatively fleeting nature of movement organizations and activity, available to operationalize the most basic understandings of social movements across countries. There have been surveys tapping self-reported participation in different sorts of political action across some countries for 
a few time periods (Dalton 1988), but these measures do not seem likely to win consensus status among scholars as indicators for the concept of social mobilization. Because of conceptual disagreements and lack of data, no one can say compellingly whether social movements are more present in some countries rather than others or whether they are becoming more important in individual countries over time. For the same reason, the comparative and historical literature is limited - mainly to broad comparisons across countries of the size and impact of individual social movements during the postwar period (e.g., Kitschelt 1986; Kriesi et al. 1995; Banaszak 1996).

In other research areas, it seems possible for there to be some synergy between the different types of work, but with little potential or unrealized potential. Perhaps needless to say, where there is little quantitative comparative work or few prospects for it, there is little chance for this synergy. In the case of revolutions, there is some quantitative work that largely corresponds to the main conceptualizations of revolutions in the literature (see Goldstone, this volume). Yet the possibilities for synergy in this area are diminished, perhaps in part by the standard conceptualization of revolutions as all-or-nothing outcomes or events. The more extensive quantitative comparative literature on collective violence, for which data are available, does not address the same subject. It seems possible that in some areas there may be both quantitative and comparative and historical work, but where researchers miss a chance for synergy by conceptualizing the object of analysis much differently or by paying little attention to one another.

In studying the causes of social policy, scholars doing comparative and historical work have embraced to an unusual degree quantitative, crossnational research as well as the work of historians. The attention has been reciprocated, and research on social policy has been the better for it. New lines of research contesting the old consensus on what was worth explaining in social policy have already produced results. It is not as if there were no room for improvement here, though, as the new ways of conceptualizing social policy have brought more questions than answers. I close with some reflections on this emerging research agenda and suggestions for contributions that comparative and historical research may make. As these lines of research develop, I hope that scholars can reflect back on what worked in the past and learn from it.

\section{Conclusion}

One of the reasons that comparative and historical work in social policy has made such dramatic progress is that there was a useful consensus on the 


\section{Development of Social Policy}

understanding of social policy. This consensus has begun to shift in the last decade, leading to important insights and empirical findings and opening up new subjects for study, as scholars have largely answered some questions based on the old consensus and have moved on. But it is worth reflecting back on what has worked in the past, conceptually speaking, to see how new understandings of social policy can be employed or altered to spur further progress.

One way this might be done further is through examining policies and programs outside the usual understanding of social policy. There has been an abundance of comparative and historical work showing that programs other than the standard ones have impacts on poverty or inequality of different sorts, and this research has shed new light on social policies and theoretical claims about them. This work seems well worth pursuing in ways that deepen further the concept of social policy and provide additional opportunities to appraise and refine theory. Some comparative and historical studies (Steinmo 1993; Howard 1997), for instance, make an excellent case for the need to take into account tax expenditures for social purposes in studies of social policy, as these tax breaks are often functional substitutes for spending programs. Yet some work needs to be done to make the idea applicable in other research settings in order to make useful comparisons among tax expenditure policies. Some tax expenditures are doubtfully redistributive, and these should be treated differently from social policy, just as many governmental expenditures have not been considered to be part of social policy. The issue of home ownership has important redistributive consequences, but has been neglected in part because it is difficult to operationalize comparatively. Here some thinking is needed to separate out what is due explicitly to state policy and how to ascertain this. From here, it should be possible to indicate how much these policies matter as compared to the standard transfer programs and services on issues such as the reduction of poverty. This would help to maximize the benefits opened by comparative and historical work on these additional aspects of policy.

The regime conceptualization was developed in work with a comparative and historical sensibility, but might be further followed up in the manner that occurred regarding the adoption of social policy. Comparative historical research can help here to ascertain when different cases sorted themselves out in these directions, as well as to appraise theoretical thinking as to why this happened. However, there has not been as much research on the initial development of the types of welfare states. Esping-Andersen's (1990) hypotheses about the development of the types have not been closely 
appraised by his own or other research. Given their more recent origins, feminist analyses of the state have had a greater focus on recent developments. It would also be worthwhile to devise comparative and historical research projects to address the question of the long-run development of different gender-based types of social policy.

Social policy regime types have advanced research in social policy but might be made more flexible as previous understandings of social policy. One way to increase the flexibility and usability of the concepts would be to modify the two main types - Esping-Andersen's regimes based on freeing workers from markets and feminist models concerned with the impact of state policy on gender equality. The degree to which states provide equal access to paid labor and ease the possibility of establishing autonomous households, as suggested by Orloff(1993b), and O'Connor (1993), seem like the most fruitful lines for further conceptual development. These dimensions might be employed to build conceptual categories that fall somewhere between policy regimes and individual programs. This sort of conceptualization would be useful for the development of theoretical argumentation that could be appraised by research of the comparative and historical kind as well as the quantitative and formal qualitative sorts.

Regime models like Esping-Andersen's have been helpful in explaining cross-national differences in retrenchment efforts (Pierson 2000c; Huber and Stephens 2001b), and these arguments have begun with the premise that the structure of social policy will influence the potential of any sort of politics. More work along these lines seems promising, with scholars paying careful attention to constructing arguments that have clear and appraisable implications across countries and policies. This is an area where comparative and historical scholars might make theoretical impacts, specifying in comparably appraisable ways the "feedback" arguments that have become so much a part of this literature and employing comparative and historical techniques to assess these arguments.

It may be useful to think of states holistically in different ways, however. Scholars studying the state have focused almost exclusively on social policy. It has been assumed that as social policy dominates and states come more to resemble welfare states, the punishing and disciplining aspects of states will diminish. This is not necessarily true, however. Recent U.S. experience has indicated that increased social spending has gone along not only with teduced military spending, but also with increased efforts toward imprisonment. State conceptualizations and theories may need to address the character of entire states, not merely the aspects of the state that provide services 


\section{Development of Social Policy}

and income protection from risks. Comparative and historical research on social policy is often based on theories of the state and politics and might link up with the literature on state-building by addressing states as such.

I think we should strive to recognize the strengths of different types of research, as scholars in this area have done. If everyone were to take this sort of approach, my task here - sorting out the contributions of comparative and historical research to a given subfield of study - would be unnecessary and probably impossible. Because scholars already work together so well in this field, fortunately the exercise is difficult.

\section{References}

Abbott, Andrew. 1992. "From Causes to Events: Notes on Narrative Positivism." Sociological Metlods and Research 20: 428-55.

Abbott, Andrew and Stanley DeViney. 1992. "The Welfare State as Transnational Event: Evidence from Sequences of Policy Adoption." Social Science History 16: 245-74.

Amenta, Edwin. 1993. "The State of the Art in Welfare State Research on Social Spending Efforts in Capitalist Democracies Since 1960." American Fournal of Sociology 99: 750-63.

1998. Bold Relief: Institutional Politics and the Origins of Modern American Social Policy. Princeton, NJ: Princeton University Press.

Amenta, Edwin, Chris Bonastia, and Neal Caren. 2001. "U.S. Social Policy in Comparative and Historical Perspective: Concepts, Images, Arguments, and Research Strategies." Annual Review of Sociology 27: 213-34.

Amenta, Edwin and Drew Halfmann. 2000. "Wage Wars: Institutional Politics, the WPA, and the Struggle for U.S. Social Policy," American Sociological Review 64: $506-28$.

Amenta, Edwin and Jane D. Poulsen. 1996. "Social Politics in Context: The Institutional Politics Theory and Social Spending at the End of the New Deal." Social Forces 75: 33-60.

Baldwin, Peter. 1990. The Politics of Social Solidarity: Class Bases of the European Welfare State 1875-1975. Cambridge: Cambridge University Press.

Banaszak, Lee Ann. 1996. Why Movements Succeed or Fail: Opportunity, Culture, and the Struggle for Woman Suffrage. Princeton, NJ: Princeton University Press.

Benoit, Ellen. 2000. "Controlling Drugs in the Welfare State: American Policy in Comparative, Historical Perspective." Ph.D. dissertation, Department of Sociology, New York University.

Berkowitz, Edward. 1991. America's Welfare State: From Roosevelt to Reagan. Baltimore, MD: Johns Hopkins University Press.

Berkowitz, Edward and Kim McQuaid. 1988 [1980]. Creating the Welfare State: The Political Econonty of Twentietb-Century Reform. Lawrence: University Press of Kansas. 
Bonastia, Christopher. 2000. "Why Did Affirmative Action in Housing Fail During the Nixon Era?: Exploring the 'Institutional Homes' of Social Policies." Social Problems 47: 523-42.

Brownlee, W. Elliot, ed. 1997. Funding the Modern Anterican State, 1941-1995: The Rise and Fall of the Era of Easy Finance. Washington, DC: Woodrow Wilson Center Press and New York: Cambridge University Press.

Castles, Francis G. 1985. The Working Class and Welfare: Reflections on the Political Development of the Welfare State in Australia and New Zealand. Sydney and London: Allen \& Unwin.

1998. "The Really Big Trade-off: Home Ownership and the Welfare State in the New World and the Old." Acta Politica 33: 5-19.

Castles, Francis G. and Deborah Mitchell. 1993. "Worlds of Welfare and Families of Nations." Pp. 93-128 in Families of Nations: Patterns of Public Policy in Westerm Democancies, edited by Francis G. Castles. Aldershot, U.K.: Dartmouth.

Cauthen, Nancy K. and Edwin Amenta. 1996. "Not for Widows Only: Institutional Politics and the Formative Years of Aid to Dependent Children." American Sociological Review 61: 427-48.

Collier, David and Richard Messick. 1975. "Prerequisites versus Diffusion: Testing Alternative Explanations of Social Security Adoption." Annerican Political Science Review 69: 1299-1315.

Cook, Linda J. and Mitchell Orenstein. 1999. "The Return of the Left and Its Impact on the Welfare State in Russia, Poland, and Hungary." Pp. 47108 in Left Parties and Social Policy in Post-Communist Eatrope, edited by Linda J. Cook, Mitchell Orenstein, and Marilyn Rueschemeyer. Boulder, CO: Westview.

Conley, Dalton. 2000. Home Ownership, the Welfare State and Cross-National Poverty Comparisons. Conference on Saving, Intergenerational Transfers, and tbe Distribation of Wenlth. Presented at the Jerome Levy Economics Institute of Bard College, Annandale-on-Hudson, NY.

Cutright, Phillips. 1965. "Political Structure, Economic Development, and National Social Security Programs." American Fournal of Sociology 70: 53750.

Dalton, Russell. 1988. Citizen Politics in Western Democracies: Public Opinion and Political Parties in the United States, Great Britnin, West Germanny, and France. Chatham, NJ: Chatham House.

de Swaan, Abram. 1988. In Care of the State: Healtb Care, Education and Welfare in Europe and the USA in the Modern Era. New York: Oxford University Press.

Dye, Thomas R. 1966. Politics, Economics, and the Public: Policy Outcomes in the American States. Chicago: Rand McNally.

Ertman, Thomas. 1997. Birth of the Leviatban: Building States and Regines in Medieval and Early Modern Europe. New York: Cambridge University Press.

Esping-Andersen, Gøsta. 1985. Politics Agninst Markets: The Social Democratic Road to Power. Princeton, NJ: Princeton University Press.

1990. The Three Worlds of Welfare Capitalism. Princeton, NJ: Princeton University Press. 
Development of Social Policy

1999. The Social Foundations of Postindustrial Economies. New York: Oxford University Press.

Esping-Andersen, Gosta and Kees van Kersbergen. 1992. "Contemporary Research on Social Democracy." Annual Review of Sociology 18: 187-208.

Flora, Peter, ed. 1986. Growth to Limits: The Western European Welfare States since World War II. New York: Aldine de Gruyter.

Flora, Peter and Jens Alber. 1981. "Modernization, Democratization and the Development of Welfare States in Western Europe." Pp. 37-80 in The Development of Welfare States in Europe and America, edited by P. Flora and A. Heidenheimer. New Brunswick, NJ: Transaction Books.

Flora, Peter, Jens Alber, Richard Eichenberg, Jürgen Kohl, Franz Kraus, Winfried Pfenning, and Kurt Seebohm. 1983. Stnte, Economy, and Society in Western Europe 1815-1975: The Growth of Mass Democracies and Welfare States. Chicago: St. James.

Flora, Peter and Arnold J. Heidenheimer, eds. 1981.The Development of Welfare States in Ezrope and America. New Brunswick, NJ: Transaction Books.

Giugni, Marco G. 1998. "Was It Worth the Effort? The Outcomes and Consequences of Social Movements." Annual Review of Sociology 24: 371-93.

Griffin, Larry. 1992. "Temporality, Events, and Explanation in Historical Sociology: An Introduction." Sociological Methods and Research 20: 403-27.

Hage, Jerald, Robert Hameman, and Edward Gargon. 1989. State Responsiveness and State Activisn. London: Unwin Hyman.

Hall, Peter A. 1986. Governing the Econonty: The Politics of State Intervention in Britain and France. New York: Oxford University Press.

Haney, Lynne. 2000. "Feminist State Theory: Comparing Gender Regimes Across Apparatuses." Annual Review of Sociology 26: 641-66.

Heclo, Hugh. 1974. Modern Social Politics in Britain and Sweden: From Relief to Income Maintcnance. New Haven, CT: Yale University Press.

Heidenheimer, Arnold J. 1981. "Education and Social Security Entitlements in Europe and America." Pp. 269-305 in The Development of Welfare States in Europe and America, edited by Peter Flora and Arnold J. Heidenheimer. New Brunswick, NJ: Transaction Books.

Hicks, Alexander. 1999. Sorial Democracy and Welfare Capitalism: A Century of Income Seczrity Politics. Ithaca, NY: Cornell University Press.

Hicks, Alexander and Joya Misra. 1993. "Political Resources and the Growth of Welfare in Affuent Capitalist Democracies, 1960-1982." American Fournal of Sociology 99: 668-710.

Hicks, Alexander, Joya Misra, and Tang Nah Ng. 1995. "The Programmatic Emergence of the Social Security State." American Sociological Review 60: 32949.

Howard, Christopher. 1997. The Hidden Welfare State: Tax Expenditures and Social Policy in the United States. Princeton, N]: Princeton University Press.

Huber, Evelyne, Charles Ragin, and John D. Stephens. 1993. "Social Democracy, Christian Democracy, Constitutional Structure, and the Welfare State." Annerican Foumal of Söciology 99: 711-49. 
Huber, Evelyne and John D. Stephens. 2001a. Development and Crisis of the Welfare State: Parties and Policies in Global Markets. Chicago: University of Chicago Press.

2001b. "Welfare State and Production Regimes in the Era of Retrenchment." Pp. 107-45 in The New Politics of the Welfare State, edited by Paul Pierson. New York: Oxford University Press.

Immergut, Ellen M. 1992. Health Politics: Interests and Institutions in Westenn Encrope. Cambridge: Cambridge University Press.

Katz, Michael. 1986. In the Shadow of the Poorlbouse: $A$ Social History of Welfare in America. New York: Basic Books.

Katznelson, Ira. 1997. "Structure and Configuration in Comparative Politics." Pp. 81-112 in Comparative Politics: Rationality, Culture, and Structure, edited by Mark Irving Lichbach and Alan S. Zuckerman. New York: Cambridge University Press.

Katznelson, Ira and Bruce Pietrykowski. 1991. "Rebuilding the American State: Evidence from the 1940s." Studies in American Political Developnuent 5: 30199.

Katznelson, Ira and Margaret Weir. 1985. Scbooling for All: Class, Race, and the Decline of the Democratic Ideal. New York: Basic Books.

King, Gary, Robert O. Keohane, and Sidney Verba. 1994. Designing Socinl Inquiry: Scientific Inference in Qualitative Resenrch. Princeton, NJ: Princeton University Press.

Kitschelt, Herbert P. 1986. "Political Opportunity Structures and Political Protest: Anti-Nuclear Movements in Four Democracies." British Fourmal of Political Science 16: 57-85.

Kriesi, Hanspeter, Ruud Koopmans, Jan Willem Duyvendak, and Marco G. Giugni. 1995. New Social Movements in Western Europe: A Comparative Analysis. Minneapolis: University of Minnesota Press.

Kuhnle, Stein. 1981. "The Growth of Social Insurance Programs in Scandinavia: Outside Influences and Internal Forces." Pp. 269-305 in The Development of Welfare States in Europe and America, edited by Peter Flora and Arnold J. Heidenheimer. New Brunswick, NJ: Transaction Books.

Lieberman, Robert C. 1998. Shifting the Color Line: Race and the Annerican Welfare State. Cambridge, MA: Harvard University Press.

Lieberson, Stanley. 1992. "Small N's and Big Conclusions: An Examination of the Reasoning in Comparative Studies Based on a Small Number of Cases." Pp. 105-18 in What Is a Case?: Exploring the Foundations of Social Inquiry, edited by Charles C. Ragin and Howard S. Becker. Cambridge: Cambridge University Press.

Lijphart, Arend. 1971. "Comparative Politics and the Comparative Method." American Political Science Review 65: 691-3.

Lustick, Ian. 1996. "History, Historiography, and Political Science: Historical Records and Selection Bias." American Political Science Review 90: 605-18.

Mahoney, James. 2000. "Path Dependence in Historical Sociology." Theory and Society 29: $507-48$. 


\section{Development of Social Policy}

Marshall, T. H. 1963. Class, Citizenship, and Social Development. Chicago: University of Chicago Press.

McAdam, Doug, John D. McCarthy, and Mayer N. Zald. 1988. "Social Movements." Pp. 695-737 in The Handbook of Sociology, edited by Neil J. Smelser. Beverly Hills, CA: Sage.

1996. "Introduction: Opportunities, Mobilizing Structures, and Framing Processes - Toward a Synthetic, Comparative Perspective on Social Movements." Pp. 1-22 in Comparative Perspectives on Social Movements: Political Opportunities, Mobilizing Structures, and Cultural Framings, edited by Doug McAdam, John D. McCarthy, and Mayer N. Zald. New York: Cambridge University Press.

Miriampolski, Hyman and Dana C. Hughes. 1978. "The Uses of Personal Documents in Historical Sociology." The American Sociologist 13: 104-13.

Mishra, Ramesh. 1990. The Welfare State in Capitalist Society: Policies of Retrenchment and Maintenance in Europe, North America, and Australia. Toronto: University of Toronto Press.

Myles, John. 1989 [1984]. Old Age in the Welfare State: The Political Economay of Public Pensions, 2nd ed. Lawrence: University Press of Kansas.

Myles, John and Paul Pierson. 1998. "Friedman's Revenge: The Reform of 'Liberal' Welfare States in Canada and the United States." Politics and Society: 25: 443-72

O'Connor, Julia S. 1993. "Gender, Class and Citizenship in the Comparative Analysis of Welfare State Regimes: Theoretical and Methodological Issues." British Foumal of Sociology 44: 501-18.

O'Connor, Julia S., Ann Shola Orloff, and Sheila Shaver. 1999. States, Markets, Families: Gender; Liberalism and Social Policy in Australia, Canada, Great Britain and the United States. Cambridge: Cambridge University Press.

Orloff, Ann Shola. 1993a. The Politics of Pensions: A Comparative Analysis of Britain, Canada, and the United States, 1880-1940. Madison: University of Wisconsin Press.

1993b. "Gender and the Social Rights of Citizenship: The Comparative Analysis of Gender Relations and Welfare States." American Sociological Review 58: 30328.

1996. "Gender in the Welfare State. Annual Review of Sociology 22: 51-78.

Orloff, Ann Shola and Eric Parker. 1990. "Business and Social Policy in Canada and the United States, 1920-1940." Comparative Social Researcb 12: 295-339.

Orloff, Ann Shola and Theda Skocpol. 1984. "Why Not Equal Protection? Explaining the Politics of Public Social Welfare in Britain and the United States, 1880s-1920s." American Sociological Review 49: 726-50.

Pampel, Fred C. and John B. Williamson. 1989. Age, Class, Politics, and the Welfare State. Cambridge: Cambridge University Press.

Patterson, James. 1986. America's Struggle against Poverty. Cambridge, MA: Harvard University Press.

Peacock, Alan R. and Jack Wiseman. 1961. The Growth of Public Expenditure in the United Kingdom. Princeton, NJ: Princeton University Press.

Pedersen, Susan. 1993. Family, Dependence, and the Origins of the Welfare State: Britain and France, 1914-1945. Cambridge: Cambridge University Press. 
Pierson, Paul. 1994. Dismantling the Welfare State? Reagan, Thatcher; and the Politics of Retrenchment. Cambridge: Cambridge University Press.

2000a. "Three Worlds of Welfare State Research." Comparative Political Studies 33: 822-44.

2000b. "Path Dependence, Increasing Returns, and the Study of Politics." American Political Science Review 94: 251-67.

2000c. "Coping with Permanent Austerity: Welfare State Restructuring in Affluent Democracies." Pp. 410-56 in The New Politics of the Welfare State, edited by Paul Pierson. New York: Oxford University Press.

Piven, Frances Fox and Richard A. Cloward. [1971] 1993. Regulating the Poor: The Functions of Public Welfare, updated ed. New York: Vintage Books.

Przeworski, Adam and Henry Teune. 1970.The Lagic of Comparative Social lnquiry. New York: Wiley-Interscience.

Quadagno, Jill. 1987. "Theories of the Welfare State." Annual Review of Sociology 13: 109-28.

1994. The Color of Welfare: How Racism Undermined the War on Poverty. New York: Oxford University Press.

Ragin, Charles C. 1987. The Comparative Metbod. Berkeley: University of California Press.

1994. "A Qualitative Comparative Analysis of Pension Systems." Pp. 320-45 in Methodological Advances in Comparative Political Economy, edited by Thomas Janoski and Alexander Hicks. New York: Cambridge University Press.

Rimlinger, Gaston V. 1971. Welfare Policy and Industrialization in Europe, America, and Russia. New York: Wiley.

Rueschemeyer, Dietrich and Theda Skocpol. 1996. States, Social Knowledge and the Origins of Modern Social Policies. Princeton, NJ: Princeton University Press.

Rueschemeyer, Dietrich and John D. Stephens. 1997. "Comparing Historical Sequences - A Powerful Tool for Causal Analysis." Comparative Social Researcb 17: 55-72.

Rueschemeyer, Marilyn and Sharon L. Wolchik. 1999. "The Return of LeftOriented Social Parties in Eastern Germany and the Czech Republic and Their Social Policies." Pp. 109-43 in Left Parties and Social Policy in PostCommunist Europe, edited by Linda J. Cook, Mitchell Orenstein, and Marilyn Rueschemeyer. Boulder, CO: Westview.

Ruggie, Mary. 1984. The State and Working Women. Ithaca, NY: Cornell University Press.

Sainsbury, Diane. 1996. Gender, Equality and Welfare States. Cambridge: Cambridge University Press.

Schneider, Saundra K. 1982. "The Sequential Development of Social Programs in Eighteen Welfare States." Comparative Social Researcb 5: 195-219.

Shalev, Michael. 1983. "The Social Democratic Model and Beyond: Two 'Generations' of Comparative Research on the Welfare State." Comparative Social Research 6: 315-51.

Sharkansky, Ira and Richard Hofferbert. 1969. "Dimensions of State Politics, Economics, and Public Policy." American Political Science Review 63: 867-78. 
Development of Social Policy

Skocpol, Theda. 1985. "Bringing the State Back In: Strategies of Analysis in Current Research." Pp. 3-37 in Bringing the State Back In, edited by Peter B. Evans, Dietrich Rueschemeyer, and Theda Skocpol. Cambridge: Cambridge University Press.

1992. Protecting Soldiers and Mothers. Cambridge, MA: Harvard University Press. Skocpol, Theda, Marjorie Abend-Wein, Christopher Howard, and Susan G. Lehmann. 1993. "Women's Associations and the Enactment of Mothers' Pensions in the United States." American Political Science Review 87: 686701.

Skocpol, Theda and Edwin Amenta. 1986. "States and Social Policies." Annual. Review of Sociology 12: 131-57.

Skocpol, Theda and Margaret Somers. 1980. "The Uses of Comparative History in Macrosocial Inquiry." Comparative Studies in Society and History 22: 174-97.

Steinmetz, George. 1993. Regulating the Social: The Welfare State and Local Politics in Imperial Germany. Princeton, NJ: Princeton University Press.

Steinmo, Sven. 1993. Taxation and Democracy: Swedish, British and American Approaches to Financing the Modern State. New Haven, CT: Yale University Press.

Stephens, John D. 1979. The Transition from Capitalism to Socialism. London: Macmillan.

Swank, Duane. 2001. Diminished Democracy? Globalization, Political Institutions, and the Welfare State in Advanced Market Economies. New York: Cambridge University Press.

Swenson, Peter. 1996. "Arranged Alliance: Business Interests in the New Deal." Politics and Society 25: 66-116.

n.d. "Labor Markets and Welfare States: Employers in the Making of the American and Swedish Systems." Unpublished manuscript, Department of Political Science, Northwestern University.

Thelen, Kathleen. 1999. "Historical Institutionalism in Comparative Politics." Annual Review of Political Science 2: 369-404.

Thelen, Kathleen and Sven Steinmo. 1992. "Historical Institutionalism in Comparative Politics." Pp. 1-32 in Structuring Politics: Historical Institutionalism in Comparative Analysis, edited by Sven Steinmo, Kathleen Thelen, and Frank Longstreth. New York: Cambridge University Press.

Tilly, Charles. 1984. Big Structures, Large. Processes, Huge Comparisons. New York: Russell Sage.

Titmuss, Richard. 1958. "Wer and Social Policy." Pp. 75-87 in Richard Titmuss, Essays on the Welfare State. London: Allen and Unwin.

Van Kersbergen, Kees. 1995. Social Capitalism. London: Routledge.

Weir, Margaret. 1992. Politics and Jobs: The Boundaries of Employment Policy in the United States. Princeton, NJ: Princeton University Press.

Weir, Margaret, Ann Shola Orloff, and Theda Skocpol. 1988. "Understanding American Social Politics." P. 3-27 in The Politics of Social Policy in the United Stntes, edited by Margaret Weir, Ann Shola Orloff, and Theda Skocpol. Princeton, NJ: Princeton University Press. 
Amenta

Wickham-Crowley, Timothy P. 1992. Guerrillas and Revolution in Latin America: A Comparative Study of Insurgents and Regimes since 1965. Princeton, NJ: Princeton University Press.

Wilensky, Harold L. 1975. Tbe Welfare State and Equality: Structural and Ideological. Roots of Public Expenditures. Berkeley and Los Angeles: University of California Press.

Williamson, John B. and Fred C. Pampel. 1993. Old-Age Security in Comparative Perspective. New York: Oxford University Press.

Wright, Gavin. 1974. "The Political Economy of New Deal Spending: An Econometric Analysis." Review of Economics and Statistics 56: 30-8.

Zelizer, Julian E. 1999. Taxing America: Wilbur D. Mills, Congress, and the State, 1945-1975. New York: Cambridge University Press. 